\title{
Transformation of urban form in Shkodër during the Ottoman period
}

\author{
Ermal Shpuza*
}

\begin{abstract}
Urban form in Shkodër is studied according to six stages during the period 1479-1913, which are reconstructed based on historical descriptions, maps, photographs, and the spatial interpretation of the Venetian cadastral registry in 1416. Like other Ottoman cities in the Balkans, the old quarters in Shkodër evolved by preserving the original medieval street network, while the new part of the city grew by expanding suburbs with dendritic street patterns and large plots along existing intercity arterial roads. The unique location of the city confined by hilly ranges and surrounded by three rivers and a lake produced a distinctive urban form due to the position of the external bazaar and the crisscrossing of arterial roads. The comparative space syntax analysis of the street network for each stage reveals a gradual transformation in the spatial structure of the city broken by two stark changes: during the early Ottoman period when the bazaar became distinctively more central in comparison to the living quarters, and after the opening of new boulevards during the late Ottoman period when the new urban center that emerged in the new city drew the spatial integration away from the historical bazaar.
\end{abstract}

Keywords: street network, space syntax, urban morphology, Albania, historical city

\section{A Frontier City Surrounded by Three Rivers}

While Shkodër (Scodra, Scutari, Skadar, Iskenderiye, Işkodra ${ }^{1}$ ) is celebrated as the foremost historic city and the cultural cradle of Albania, little is known of its history of urban form. Historical and archeological research on the city so far has produced scant findings on the fortifications and the extent of the urban area during the Roman, Byzantine, and medieval periods (Hoxha, 2003; Korkuti \& Petruso, 1993; Kamsi, 1976), while the study of built form during the Ottoman period (1479-1913) has been limited to key public buildings, infrastructure and military works (Kiel, 1990), and domestic architecture (Riza, 1972) without addressing the urban form, despite the latter undergoing profound changes during this time. The paper presents an attempt to reconstruct Shkodër's historical urban form during the last five centuries and shed light on the spatial transformation while the city changed from an important Venetian stronghold in northwest Albania to a prosperous Ottoman provincial center. The study employs the comparative space syntax analysis of the city's street network in six historical stages.

\footnotetext{
${ }^{1}$ Latin, Italian, Slavic, and Turkish exonyms are shown in brackets in the first mention of key toponyms as they appear in historical literature.
} 
For the most part, the transformation of Balkan cities during the Ottoman period is characterized by the process of Ottomanizing existing Byzantine cities through the process of inserting Ottoman architecture into the medieval fabric, and the extension of suburbs with sparse dendritic street patterns. Cities established during the Ottoman period in the Balkans are rare, with examples such as Sarajevo (Bosna Saray), Novi Pazar (Yeni Pazar), Elbasan, Giannitsa (Yenice), and Ruse (Ruscuk). Since the new part of Shkodër grew disjoint from its medieval core by weaving an Ottoman urban fabric along intercity arterial roads and forming a new urban center away from the historical bazaar, the paper inquires whether Shkodër's urban formation shares the characteristics of a new Ottoman city built from scratch.

The city is located not far from the historical western frontier of the Ottoman Empire in the Balkans. The frontier closely coincides with the Theodosius Line, the demarcation between western and eastern parts of the Roman Empire, which later survived as the most extraordinary divide in the Mediterranean (Braudel, 1972), becoming the fault line between Roman Catholic and Greek Orthodox Churches. During the rule of the Bushati family (1751-1831) Shkoderr grew into an important economic hub as the center of a de-facto autonomous pashalik. Despite its remoteness from Istanbul (Dumont, 1874), the access to the Adriatic via the river port made the city a network system node (Hohenberg and Lees, 1995) of commerce from Anatolia to Venice (Pedani, 2008) and the illicit trade to the eastern Mediterranean (Blumi, 2010). From this viewpoint, the paper inquires whether Shkodër's peripheral location in the Ottoman sphere and its close historical links with Ragusa and Venice produced different features of urban form compared to other Turko-Balkan cities.

The urban form of Shkodër and its transformation over time is tied to the unique physiography of the plain bound by the mountainous range of Tarabosh-Rozafa-Tepe, the shores of Lake Shkoderr, and three rivers Bunë (Barbana, Bojana, Boyana), Kir (Clausula, Clia), and Drin (Oriundus, Drino, Dirin). While the Bunë has maintained a stable course from the lake to the Adriatic, the Kir has altered its course on the upper plain where the new city expanded, and its old beds were transformed over the centuries into canals for operating mills (Figure 1). After extraordinary floods in 1846, the Drin, which is the second largest river of the Adriatic, changed course to flow northward into the Drinasë stream (Drinassa, Drimac) along the embankment of the old city, and subsequently into the Bunë. By 1858, the northern distributary became the main one causing the erosion of large parts of the medieval quarters of Tabak and Ajasëm, the frequent flooding of the Bazaar, and the creation of sandbars in the Bunë's delta that blocked the access of large ships from the sea to the river port. The study of Shkodër's transformation is therefore discussed considering changes to the riverine morphology over time.

\section{Hypothetical Reconstruction of Historical Urban Form}

While the transformation of the city occurred gradually, the study focuses on six stages: 1) 1446, during the Venetian period (1396-1479); 2) 1646, by which time the city had been established as an Ottoman sanjak center; 3) 1746 when the city was divided into two parts during the feudal struggles between two main clans; 4) 1846, at the peak of its economic development just before the river Drin's new branch first appeared near the city; 5) 1858 when the Drin's northern distributary became the main one leading to the erosion of vast areas of the old quarters; 6) 1913, at the end of the Ottoman rule by which time new boulevards were opened in the spirit of Tanzimat modernizations.

The study of Shkodër's transformation is hampered by the lack of historical maps, as is the case for other cities in the region (Karamustafa, 1992). So far, we know of no map of the city produced during the Ottoman period. The earliest accurate plan of the city, showing the street network and the buildings, was produced by the British in 1913 (Hobbs, 1913) (Figure 1), while the first known aerial photograph was taken by the Italian Airforce during WWI (Royal Italian Navy, 1918) showing the Bazaar and the southern half of the new city. I have employed two subsequent maps to 
determine the location of mill waterways and plot boundaries (Rossi \& Boroli, 1923; D’Ascensi and Miserocchi, 1938).

To reconstruct the city's form during the Venetian period, I have augmented the historical research (Jireček, 1916; Kamsi, 1976; Schmitt, 2001; Šufflay, 1924; Valentini 1967) with a spatial interpretation of the Venetian cadastral registry of Shkodër in 1416 (Zamputi, 1977), which comes only in text and lacks drawings. While the toponyms of the villages in the registry have, for the most part, survived unchanged to the present, almost all toponyms within the urban area and the contado (contrata) ${ }^{2}$ of Sopra Scutari and Soto Scutari (Upper Shkodër and Lower Shkodër) have been replaced ${ }^{3}$. Since the listing of the properties in the villages both on the upper and lower plains are listed in a clockwise order starting with those closest to the city, I have used a clockwise listing of properties in the contado to determine their location.

To reconstruct Shkodër's urban form during the Ottoman period, I have relied on Bushati's seminal work on the history of the city (Bushati, 1998), which gives invaluable descriptions of quarters, streets, waterways, mills, the bazaar, and public buildings; the accounts by Evliya Çelebi who visited the city in 1662 (Dankoff and Elsie, 2000); historical photographs starting in 1863 (Elsie; Marubi); and writings by European travelers and envoys to the city during the 19th century. For the reconstruction of the streets in the quarters eroded by the Drin, I have relied on the plot boundaries shown in the 1938 map.

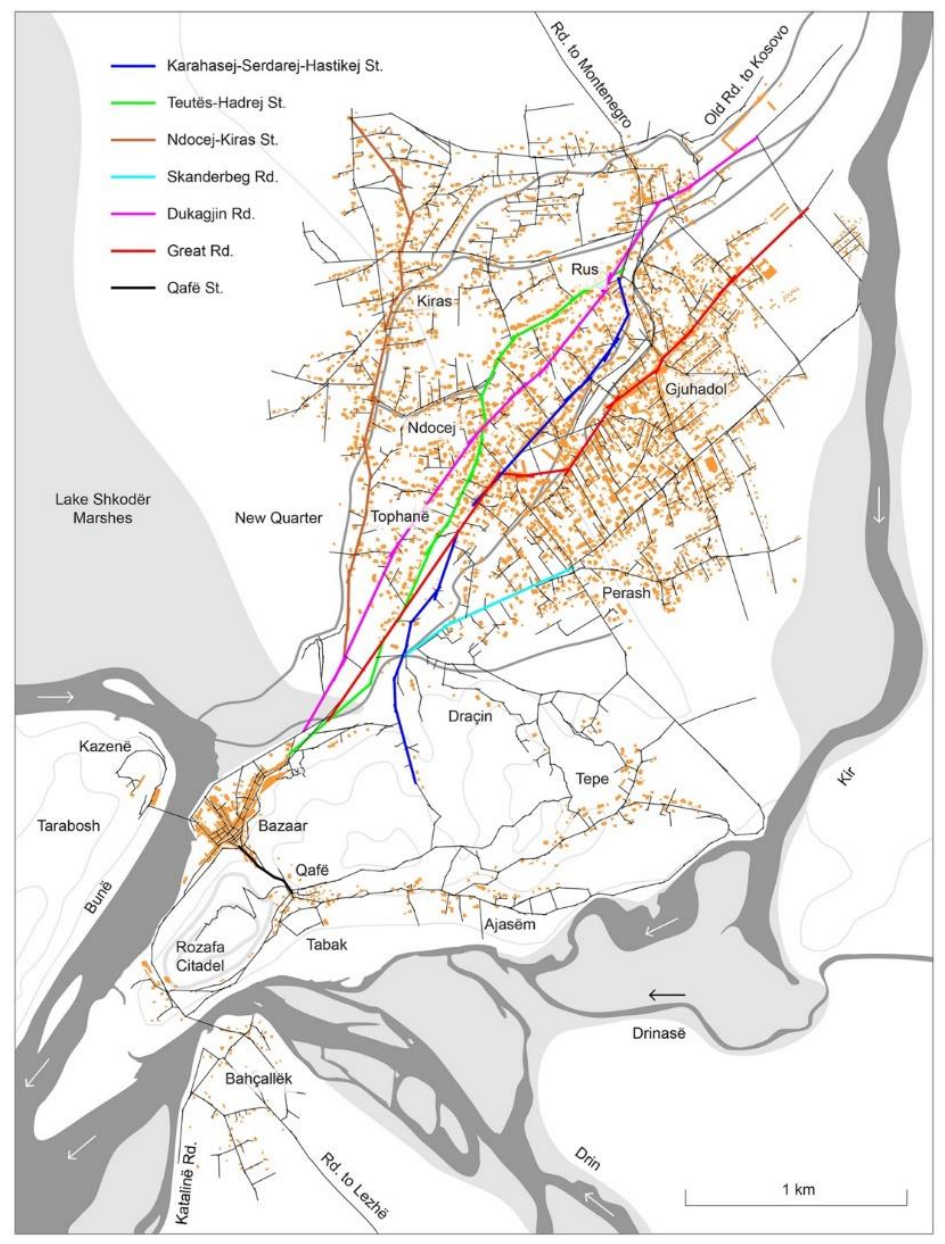

Figure 1 Street network, building footprints, and main toponyms of Shkodër in 1913 drawn according to the British map (Hobbs, 1913). Marshes and floodplains are shown in light gray, waterways in gray, and main arterials in color as per the inset legend.

\footnotetext{
${ }^{2}$ Arable land, pastures, vineyards, and forests owned by citizens within a radius of about 5 kilometers around the city (Schmitt, 2001: 96).

${ }^{3}$ It is likely that during the medieval times urban dwellers used different toponyms from the rural population, which were lost after the emigration of the entire city to Venice as per the treaty of the surrender of Shkodër after the second Ottoman siege in 1479.
} 


\section{The Use of Space Syntax Analysis for Historical Research}

Space syntax is a theory and set of analytical techniques that address the spatial description of the built form from a social viewpoint (Hillier and Hanson, 1984). For a concise review of main theorems, methods and applications, see (Peponis and Wineman, 2002; Bafna, 2003). Space syntax

Page | 118 studies of cities have usually employed axial map representations, which are constructed by drawing the fewest and the longest straight lines to cover the open public space of streets and squares and are analyzed according to graph-theoretic measures. Relational patterns among the lines are studied to explain both the social dimensions of the urban form and the spatial aspects of society. In this study, I use the topological measures of connectivity C, integration I (topological depth relativized for size), choice B (betweenness centrality), spatial intelligibility (the regression coefficient $R^{2}$ in the plot $C$ vs. I), and the geometric measure of street length $L$.

A growing number of studies have employed space syntax methods to understand the spatial transformation of cities over time (Griffiths, 2010). Some have addressed urban transformation based on comparisons among cases within countries and regions such as Adriatic and lonian littoral (Shpuza, 2009; Shpuza, 2014), Anatolia and Turkey (Kubat, 1997; Topçu, 2019), Brazil (Medeiros et al., 2003), England and Iran (Karimi, 2000; Azimzadeh \& Klarquist, 2003). Others have focused on single cases to investigate changes to the urban form brought by colonization, independence, and modernization such as Algiers and Zanzibar (Rashid, 2021), Amsterdam (Read, 2000), Belgrade (Fouillade Orsini, 2018), Istanbul (Kubat, 1999), and Zagreb (Zaninović et al., 2018). On the one hand, these studies have contributed techniques for the historical study of cities, on the other hand, they have amassed a database of historical research that enables comparative interpretations, especially with the cases in the Balkans and the Ottoman Empire, which share a socio-cultural context with Shkodër.

\section{The Venetian Shkodër}

The understanding of urban form during the Venetian period is crucial for two main reasons: First, that the social norms in medieval Albanian cities (Nadin, 2010; Schmitt, 2001), likely produced a different spatial culture and urban form compared to the Ottoman city, which reflected different customs brought by the Islamic influence; Second, since the medieval street network and intercity arteries formed the basis on which the Ottoman-era city expanded.

During the medieval period, the city was composed of three main parts: the quarters within the citadel on top of Rozafa hill; the quarters outside the walls (borgo, varosh), which were located on the slopes around the citadel and extended eastward to present-day Ajasëm, and two quarters of Casene and Gardens across the rivers, which were connected via bridges ${ }^{4}$. The medieval market was smaller than the modern-era bazaar and occupied its southern sector. The medieval urban fabric would have been constituted with an altstadt street pattern (Marshall, 2005) like medieval quarters preserved inside the citadels of neighboring cities of Ulqin (Dulcigno, Ulcinj, Ülgün) and Tivar (Antivari, Bar) (Bošković, et al., 1981; Mijović and Kovačević, 1975). The medieval quarters were organized along a few main arteries ${ }^{5}$. Via del Canaro (Bërdicë Rd. ${ }^{6}$ - Via Publica (Dukagjin Rd.) coincided with the major Roman road from Dyrrhachium to Doclea-Narona and connected the Gardens with the market and further north with the hamlet of Oliari ${ }^{7}$. There, the road bifurcated

\footnotetext{
${ }^{4}$ The bridge on Bunë during the Venetian era was located to the south of the modern-era bridge, near the Church of St. Blaise, part of the quarter of Ragusan merchants.

${ }^{5}$ In the cadastral registry, the streets inside the urban area are indiscriminately referred to as via de comun (commune streets), whereas streets in Sopra Scutari and Soto Scutari are explained with specific names (Zamputi, 1977).

${ }^{6}$ Streets are referred to with names used until WW2, as in the 1923 map.

${ }^{7}$ Oliari (Zamputi, 1977: 30, 256) is mentioned in 1395 as the residence of Konstantin Balsha (Balšić) (Miklosich, 1858: 228). The hamlet did not vanish, as claimed by Jireček (1916: 110), but likely survived as Rus, which is first mentioned by Bolizza in 1614 (Zamputi, 1963 : 260).
} 
into Via Schiavanesca (Tuz St.) leading to Montenegro, and Via Tartaresca ${ }^{8}$ (Dukagjin Rd.) leading to Drisht and further to Kosovo (Figure 2(a)). A second arterial, Via del Drinase extended along the right bank of Drinasë to the south of the citadel and survived until the erosion by the Drin in 1858. Given the frequent movements of the Kir to the east of the city ${ }^{9}$, it is likely that the two lesser arterials Oliari-Tepe and Zdrale-Perash-Tepe were not opened yet. Two main canals through the upper plain of Sopra Scutari, Fossado de Oliari and Fossado de Bucem, passed by the namesake hamlets and discharged into Bunë to the north of the market (Figure 2(b)). The canals maintained the same location and operated mills until 1929 (Bushati, 1998: v2, 385).

The syntactic analysis of Shkodër's street network during the Venetian period reveals an Lshaped integration core that includes the arterial road above the market and Qafë St. (Figure 1). The core is distributed gradually to include the loop at the base of Rozafa hill, while the quarter within the citadel is the most segregated area from the rest of the city. The lines with the highest choice include Qafë St., the street above the market, and the main street outside the walls linking the citadel with the varosh below. From there, the choice values are gradually distributed to include the loop street at the base of the hill and the two bridges. Shkodër's spatial structure thus resembles medieval city centers across the Adriatic (Shpuza, 2009) and some pre-Ottoman cities in Anatolia (Kubat, 1997), while the low integration of the city overall (Table 1) is to be attributed more to the separation of the city's quarters due to the physiographic constraints of the hilly terrain and the rivers rather than the organization of street patterns.
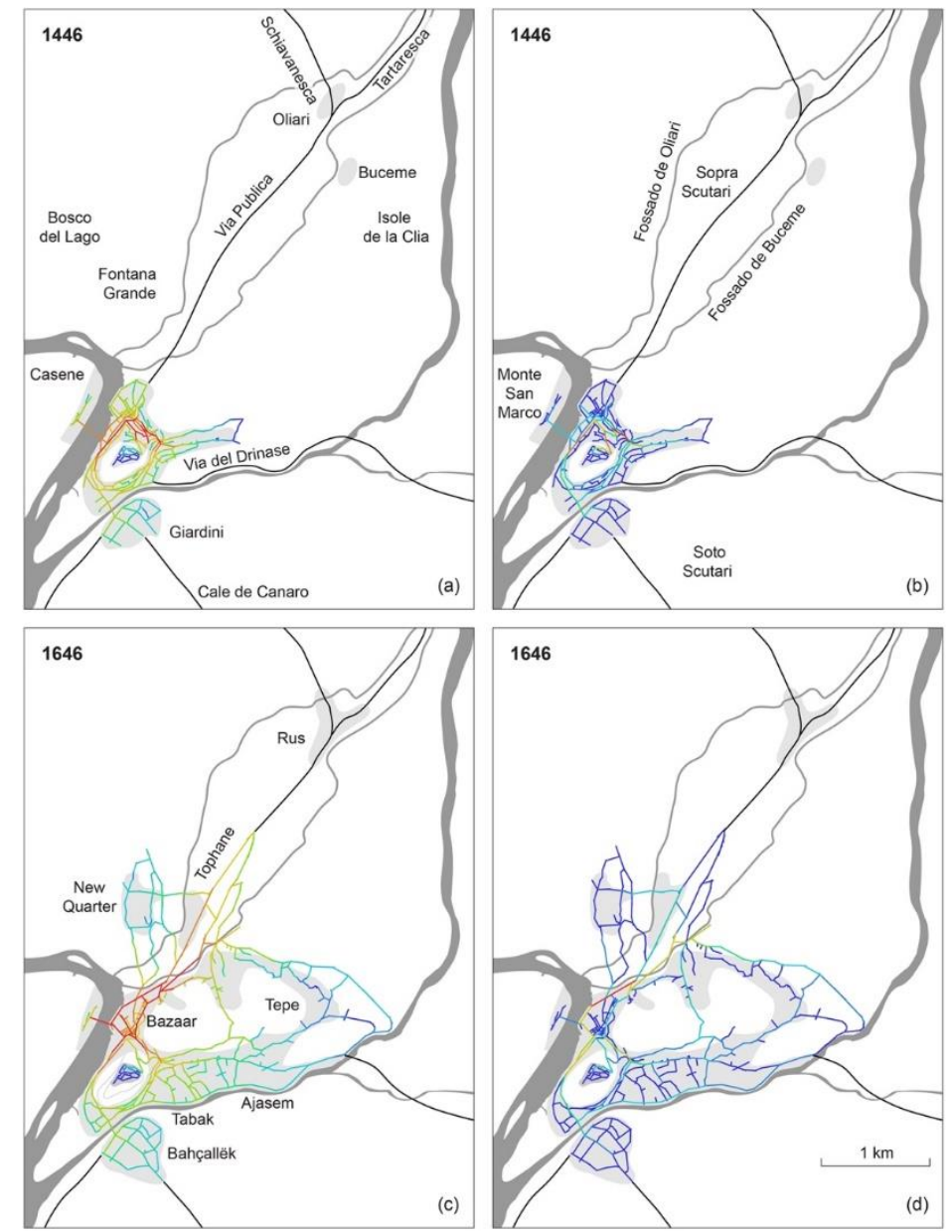

Figure 2 Axial map of Shkodër's street network during the Venetian period (1446) and early Ottoman period (1646) colored according to values of integration $(a, c)$ and choice $(b, d)$.

\footnotetext{
${ }^{8}$ Schiavanesca (Slavic) refers to the territory of Montenegro, while Tartaresca (Tatar), refers to couriers used at the time since parts of the Balkans had already fallen under Turkish rule.

${ }^{9}$ As indicated by the toponym Isole de la Clia (Kir Islands), located to the east of Buceme (present-day Gjuhadol).
} 


\section{Shkodër During the Early Ottoman Period}

Shkodër was the last Albanian city to fall to the Ottomans after the long siege of 1478-1479, during which time all the surrounding medieval cities - Balëz (Balezo), Drisht (Drivasto), Sardë (Sarda, Sardoniki), Danjë (Dagno), Sapë, Shas (Suazzo, Svač), and Zhabjak (Sabiach, Žabljak

Page | 120 Crnojevića) - were obliterated and reemerged only as insignificant villages. The city survived and was chosen as the center of an Ottoman provincial center. Its resilience is attributed not only to the powerful fortress located on an inaccessible hilltop controlling the passage between the two plains and the navigation between the sea and the lake, but also to the presence of waterways that supported trade, provided water, and operated watermills and tanneries.

During the early Ottoman period, the city consisted of two main parts, the living quarters and the bazaar, since the citadel now retained only military functions (Kiel, 1990). The quarters had expanded on the hills to the north and east of the citadel ${ }^{10}$ (Figures $3(\mathrm{a})$ and (c)). The bazaar had extended to the north of the medieval market, and due to the confinement in the narrow strip of land between the riverfront and the hills (Figures $3(b)$ and (d)), it related to the rest of the city as an exobazaar (Busch-Zantner, 1932), a position it maintained even after the city expanded on the upper plain. After the urban expansion had captured all the sides of Tepe hills, two suburbs11 appeared on the upper plain - once the Venetian contado of Sopra Scutari - disjoint from the medieval city by the marshes to the north of the Bazaar (Figure 2(c).
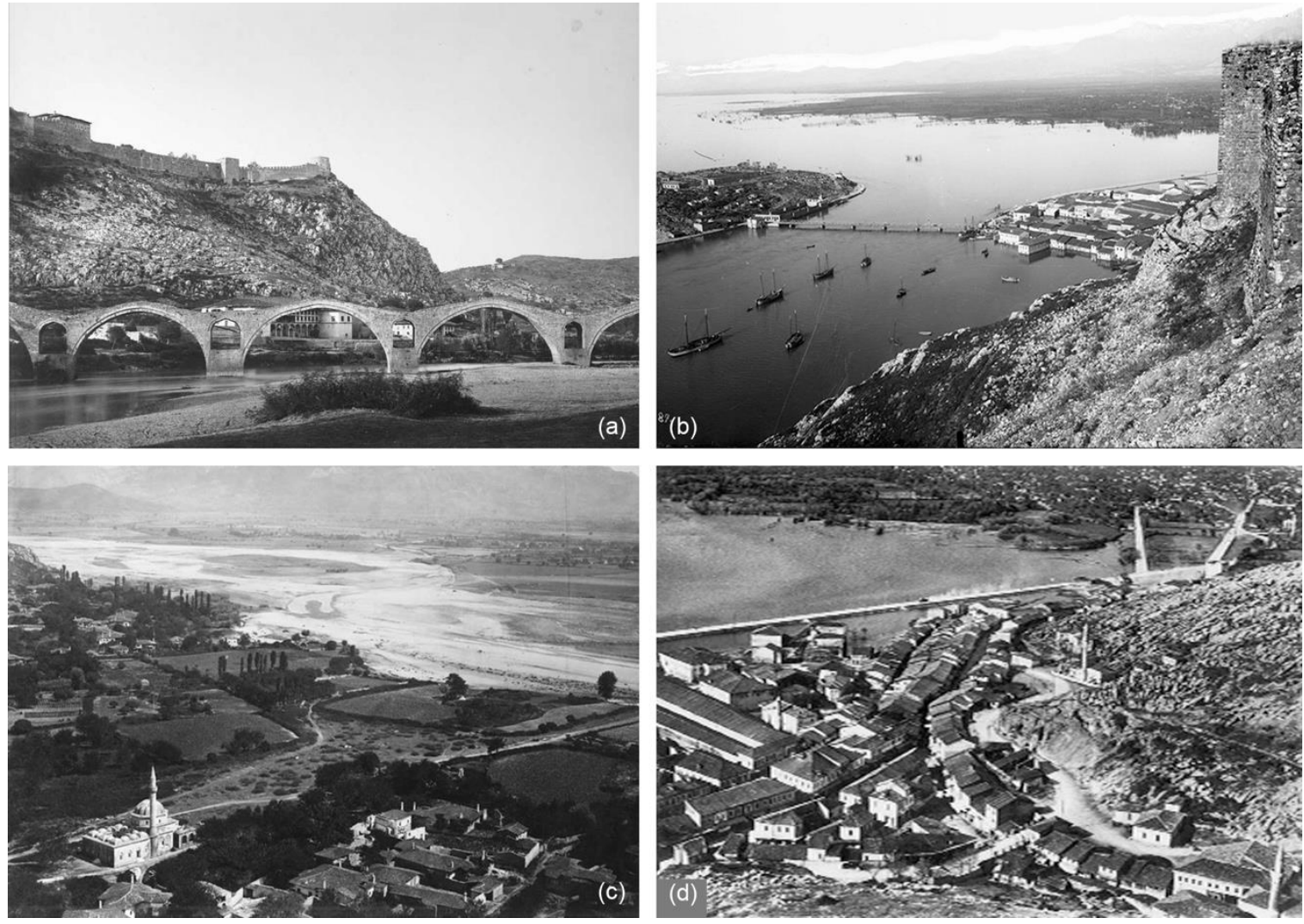

Figure 3 Old quarters of Shkodër in 1863: a) looking northeast, showing bridge on Drinasë/Drin, the citadel with Venetian fortifications, and the remnants of Tabak quarter; b) north from the citadel, showing the Bazaar and the bridge on Bunë; c) southeast from the citadel, showing the erosion by the Drin and the remnants of Tabak quarter; d) looking northwest, Bazaar confined between the riverfront, the marshes, and the hills.

\footnotetext{
${ }^{10}$ Evliya Çelebi describes Shkodër in 1662 as a town of 15 quarters, which are located around the citadel, the bazaar, 1800 houses, and 11 mosques (Dankoff \& Elsie, 2000). While the low elevation varosh quarters were rebuilt during the Ottoman period, those high up on the hill were abandoned after being destroyed during the first siege in 1467 (Kamsi, 1976).

${ }^{11}$ New Quarter and Tophanë, which was established after the construction of the mosque in 1617 (Bushati, 1998: v1, 98).
} 
The spatial structure of the early Ottoman Shkodër exhibits two significant differences to the medieval city: First, the integration core had expanded north to include all the streets circumventing the Bazaar (Figure 2(c)), of which the riverfront promenade has the highest choice controlling the through-movement among all parts of the city (Figure 2(d)). The integration core still included Qafë St. (Figure 1) - the entrance to the Bazaar from the east -, which had attracted the buildings of the court, police, and hotels (Bushati, 1998: v1, 64-69). Second, while the integration core in the Venetian city included the living quarters at the base of the hill, the living quarters in the early Ottoman period are markedly segregated in contrast to the bazaar. Also, as the city expanded during this period, both its integration and intelligibility dropped (Table 1). However, such change is attributed to the stretching of the city around the hills since the streets maintained their medieval character, lacking any application of Islamic dendritic patterns.

Table 1 Measures of axial map analysis of Shkodër's street network compared across six historical stages 1446-1913, and the new part of the city in 1913 considered separately: number of axial lines $N$, mean values of length $L$, connectivity $C$, integration $I$, and normalized choice $B$, and the index of intelligibility measured with the regression coefficient $R^{2}$ in $C$ vs $I$ plots.

\begin{tabular}{lllllll}
\hline Year & $N$ & $L$ & $C$ & $l$ & $B$ & $R^{2}$ \\
1446 & 317 & 76.8 & 3.016 & 0.539 & 0.071 & 0.135 \\
1646 & 536 & 95.8 & 2.855 & 0.409 & 0.062 & 0.076 \\
1746 & 828 & 95.6 & 2.833 & 0.412 & 0.044 & 0.072 \\
1846 & 1003 & 103.1 & 2.891 & 0.434 & 0.036 & 0.091 \\
1858 & 986 & 100.8 & 2.856 & 0.442 & 0.036 & 0.102 \\
1913 & 1313 & 99.6 & 2.847 & 0.555 & 0.023 & 0.1 \\
1913 (new) & 815 & 111.8 & 2.94 & 0.747 & 0.024 & 0.193 \\
\hline
\end{tabular}

\section{Shkodër During the Middle Ottoman Period}

As the city grew thanks to the manufacturing and the flourishing trade across the Mediterranean (Shkodra, 1984), additional suburbs were formed on the upper plain ${ }^{12}$, according to the Ottoman urban strategy of the time (Krstikj, 2013; Yenen, 1992). The upper plain was preferred to the lower one, despite its exposure to northern winds, given the presence of canals that operated mills, and the high quality of underground water. The new suburbs attracted a mixed population of Muslims and Catholics ${ }^{13}$, although, by the beginning of the 19th century, the Catholics had concentrated in the northeast of the new city. The new suburbs were centered along medieval arterials, at their crossings with the canals, and around the medieval hamlets.

By the first half of the 18th century, the suburbs on the upper plain had expanded to produce a city equally split in two by the marshes. Shkodër's spatial divide mirrored the schism between the Bushati clan, which controlled the old quarters, and the Çausholli and Maxharri clans, which controlled the new suburbs (Ippen, 1907: 25). The city's spatial structure around 1746 reinforces the transformation that had started during the early Ottoman period: spatial segregation of the quarters and the integration of the central arterials and the bazaar, as indicated by comparable values of syntactic measures between 1646 and 1746 (Table 1). The integration core had extended further to the north to include Dukagjin Rd. (Venetian-period Via Publica), followed by three other

\footnotetext{
${ }^{12}$ As indicated by the dating of the new mosques: Rus in 1711, Ndocej in 1723, and Perash in 1745 (Bushati, 1998: v1, 183, 189, 199)

${ }^{13}$ Catholics were allowed to settle in the city in 1700, starting in Tophanë (Bushati, 1998: v1, 101), while the construction of new churches and seminaries was permitted in 1851.
} 
arterials: 1) Ndocej-Kiras St., which alternates on both sides of Kiras (Oliari) canal providing a shortcut connection to Montenegro; 2) Karahasej-Serdarej-Hastikej St., which used to connect Rus with Qafë and Drinasë Rd. over the hills and bypassing the Bazaar; and 3) Teutës-Hadrej St., which starts from the Bazaar and meanders on both sides of Dukagjin Rd. (Figure 1, Figure 3(a)). This set of arterials, which created the spatial backbone of the new city, is quite peculiar when compared to arterial roads in Turko-Balkan cities in general (Pinon, 2008), and the neighboring vilayet centers of Skopje (Shkup, Üsküp), Bitola (Manastir), and Ioannina (Janinë, Yanya) in particular (Krstikj, 2013; Shundovska, 2015; Barbie du Bocage, 1820), where arterials fan out of the bazaars creating triangular superblocks. The position of Shkodër's original arterials was dictated by the narrow strip of land between the canals (Fossado de Oliari and Fossado de Bucem) while negotiating the crossing of the Kir's changing route. Their original role of connecting the medieval city with the surrounding region and beyond was augmented to facilitate the connection of the new neighborhoods with the bazaar during the Ottoman period.
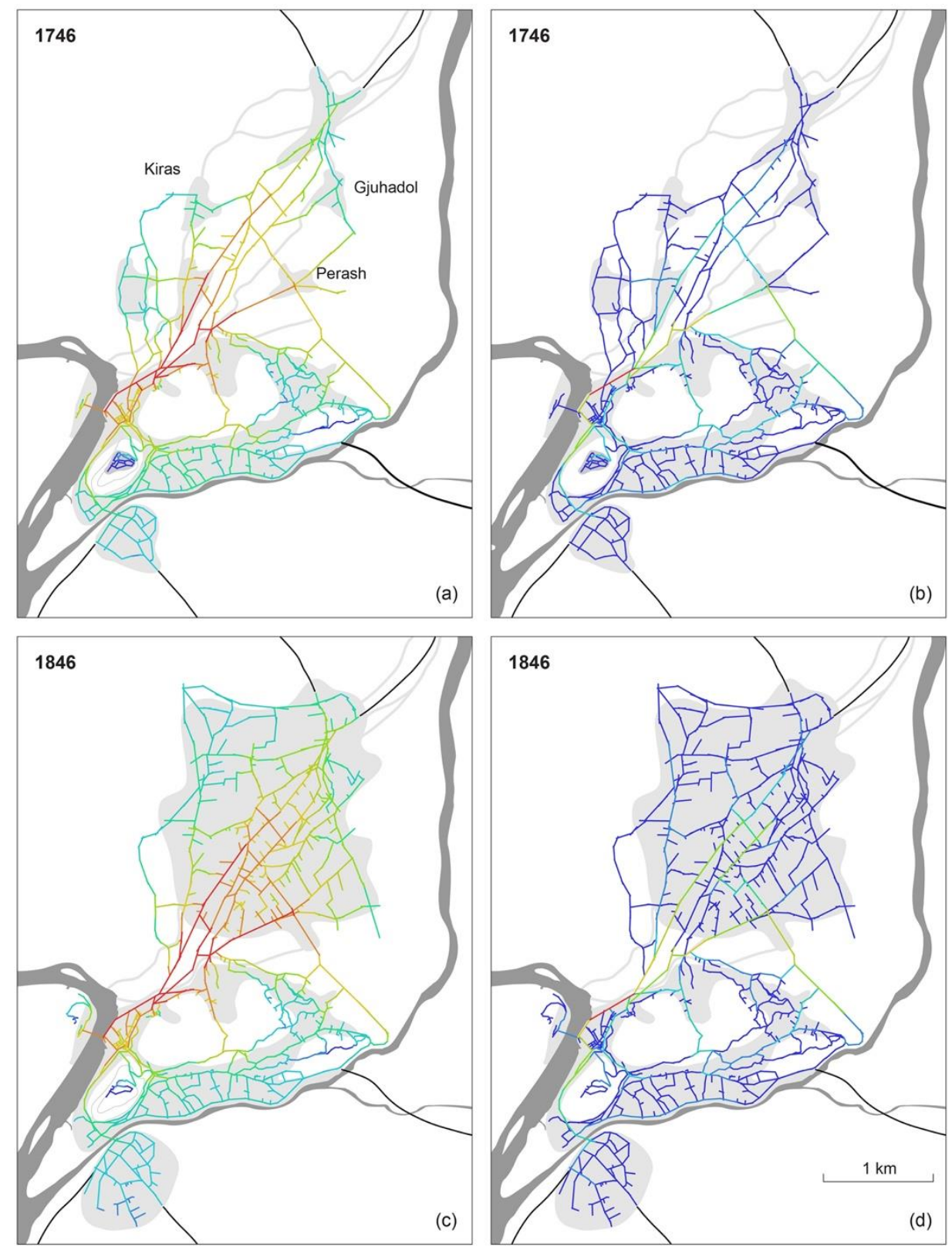

Figure 4 Axial map of Shkodër's street network during the middle Ottoman period (1746) and (1846) colored according to values of integration $(a, c)$ and choice $(b, d)$. 
The street network in the upper plain developed through the process of weaving new streets onto the existing medieval arteries, although at this stage the network was still sparse ${ }^{14}$. The new streets closely matched the patterns of cul-de-sacs and zigzagging alleys found throughout Ottoman cities in the Balkans (Pinon, 2008), which reflect the social norms brought by the Islamic culture centered on the privacy of households and the lack of connections between the quarters, although they were wider than traditional Islamic cities. The streets were lined with high stone walls that usually lacked windows and were punctured only by gates whose size and detail symbolized the household status.

Between 1746 and 1846, the gravity center of the city had moved further north, as additional streets were open in the upper plain due to the subdivision or internal blocks and by the extension of peripheral streets both to the west and east. However, the spatial structure of the city shows little change both in terms of integration and choice during this time (Table 1), reinforcing the contrast between highly integrated north-south arterials and segregated residential quarters, and the complete lack of direct east-west connections between the quarters.

\section{Shkodër During the Late Ottoman Period}

The formation of the new city occurred alongside the maturing of Shkodër's traditional çardak house as a subtype of the Ottoman sofa house (Riza, 1972; Shpuza, 1995). In the old quarters, the house adopted to the land subdivision and medieval street network of the old quarters, occupying narrow lots with small yards and sharing party walls (Figure 3(c)), giving these quarters the character of an Ottomanized city. In the new quarters, the house was surrounded by large gardens (Figure 5(a)), and together with public buildings such as mosques, madrasas, baths, shops, and cemeteries, it crystallized into the urban fabric of a new Ottoman city.

By the mid 19th century, the city continued its shift on the upper plain, despite having passed its economic zenith following the end of the autonomous pashalik, the rerouting of trade routes in the Balkans, and the Mediterranean, and the population loss due to plague. The urban densification and expansion of the new city were accelerated by the relocation of Muslims from the old quarters after the diversion of the Drin in 1858, and the growth of Catholic quarters in the eastside (Gruber, 2006). While the traditional house was equally used across the religious divide (Figures $5(a)$ and (b)), plots and urban blocks were generally smaller in the Catholic quarters, thus producing scalar disparities in the built form, which are attributed more to differences in economic status than social norms. Despite the erosion of substantial parts of old quarters in 1858, the spatial structure of the city maintained the status quo, with small increases in spatial intelligibility (Table 1), while the Bazaar promenade kept its role as the street controlling most through movement in the city (Figures $6(a)$ and (b)).

\footnotetext{
${ }^{14}$ In 1846, three blocks on the west side of the new city exceeded $0.2 \mathrm{~km}^{2}$ in area.
} 
Page | 124
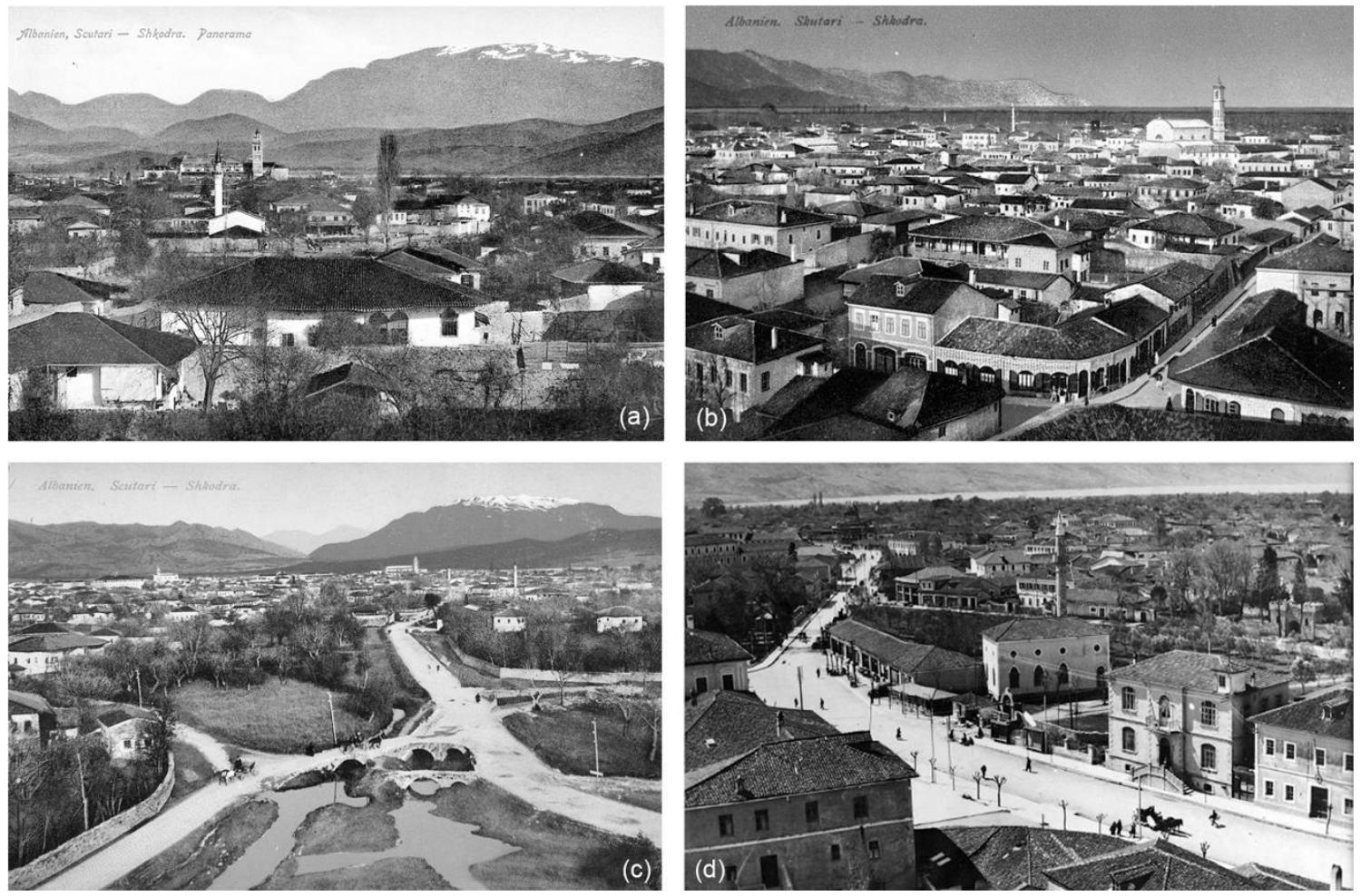

Figure 5 New part of Shkodër circa 1917: a) traditional houses with large gardens in Muslim quarters; b) densely clustered traditional houses in Catholic quarters; $c$ ) marshes separating the southern edge of the new city from the Bazaar; d) Great $\mathrm{Rd}$. in the new city center.

During the second part of the 19th century, the new city had densified adequately in the upper plain and the integration core had expanded sufficiently northward, to give rise to a new urban center. The new center developed between Parrucë and Gjuhadol, rather than further west at Rus, where the two Venetian era roads split, given the extension of the city to the northeast. The consolidation of the new center was accelerated after several public works projects were completed, as per the Tanzimat modernization efforts across the empire (Çelik, 1986). The new boulevard Great Road (Udha e Madhe) connected the new center directly with the Bazaar by cutting through the middle of the old arterials; a second boulevard Skanderbeg Rd. connected Perash quarter in the east with the Bazaar; and a new administrative and military complex was built along Great Rd. (Tuzi et al., 2014). The opening of Great Rd. was followed by the construction of new shops along its northern segment which transferred some retail functions from the exobazaar to within the new city. The opening of the new boulevards led to the most notable increase in the city's spatial integration over the entire period of investigation (Table 1), and the shifting of the segment with the highest choice from the Bazaar to Great Rd. in the new city (Figure 6). Also, the integration core was strengthened into the Great Rd. and diminishing the role of arterials such as Dukagjin Rd. and Skanderbeg Rd.

By the end of the Ottoman period, the new city had matured by drawing all the administrative and military functions from the citadel, and a proportion of retail functions away from the old bazaar. The original medieval quarters had become further segregated from the new quarters and had rarified into remote suburbs of the new city. The spatial analysis of the new city, removing the old quarters and the bazaar, shows the highest integration and intelligibility of all historical stages (Table 1). Nevertheless, Shkodër's spatial integration and intelligibility by the end of Ottoman rule in 1913 are low compared to many contemporary cities in the region, given the lack of east-west connections between the quarters. 

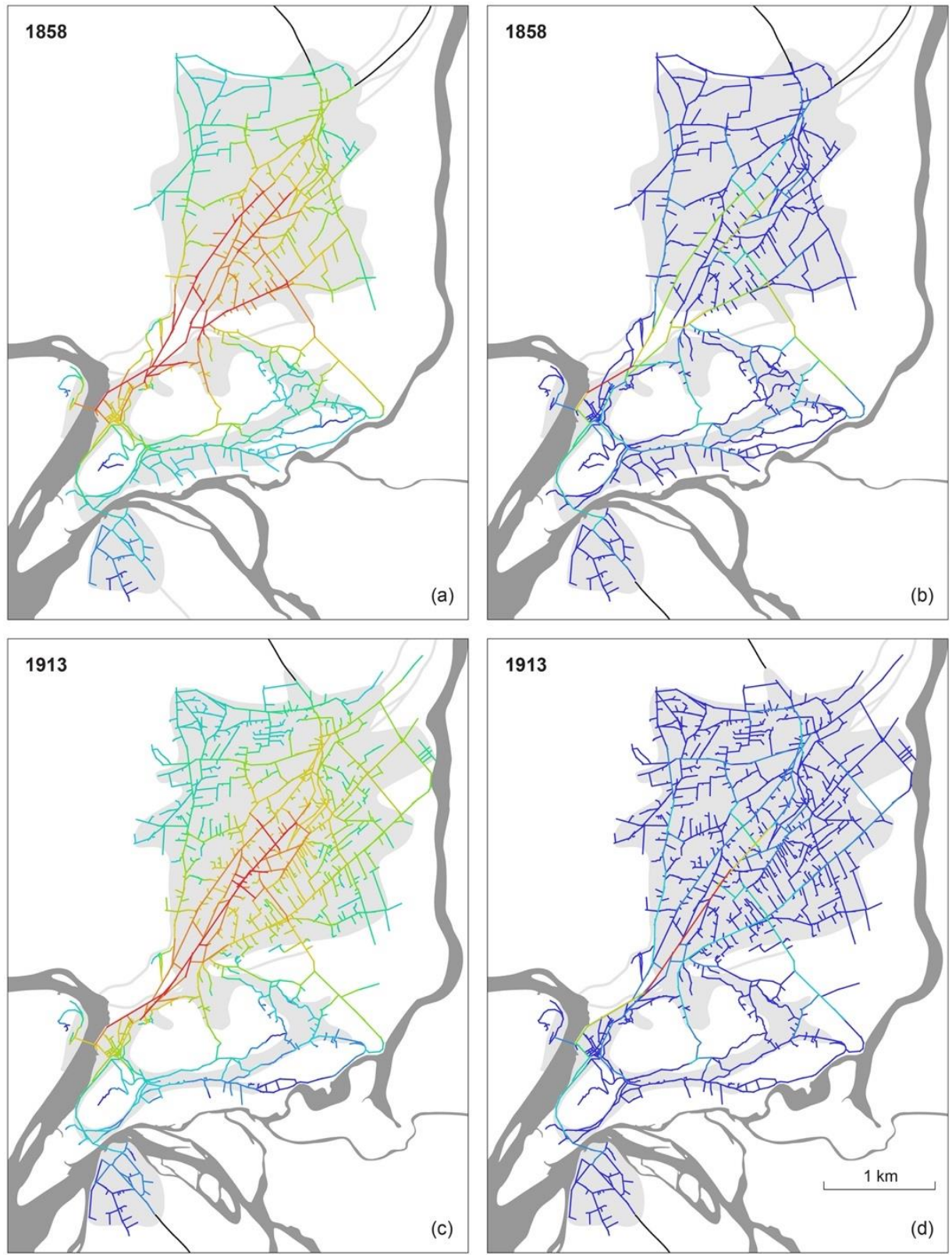

Figure 6 Axial map of Shkodër's street network during the late Ottoman period after the diversion of Drin (1858) and the opening of new boulevards (1913) colored according to values of integration (a, c) and choice (b, d).

\section{Conclusion}

Shkodër followed similar transformation processes to other Balkan cities whereby, on the one hand, the old quarters were Ottomanized after the insertion of Ottoman architecture into the medieval fabric while preserving unchanged the street network and land subdivision, and on the other hand, new suburbs developed as Ottoman urban fabrics of sparse dendritic street networks with large plots that accommodated detached houses surrounded by gardens.

The unusual physiography of the terrain surrounded by three rivers, two of which had changed course over time, led to Shkodër's unique urban form and transformative processes: First, given the presence of marshes north of the Bazaar, the new quarters developed disjoint leading over time to the crystallization of a new city away from its medieval center. Second, the main arterials that started from the Bazaar did not radiate into triangular superblocks as in other Balkan cities, rather they crisscrossed in the narrow strip of land bound by the canals. Third, due to the shifting of the Kir river, the eastern part of the upper plain became suitable for development later leading to a 
gradual northeast expansion of the city thus a peculiar redistribution of the roles of the arteries in structuring the street network over time. Fourth, the erosion of the medieval quarters after the diversion of the Drin led to both the densification of the new city and the gradual segregation of the remaining old parts.

Shkodër is located not far from the fault line that divides east and west, surrounded by a Page | 126 hinterland that partially converted to Islam and partly maintained the Roman Catholic faith. After the entire urban population emigrated to Venice in 1479 , Shkodër originally reemerged as a city with a Muslim population, while Catholics were allowed to settle only in 1700 . By the second half of the 19th century, the Catholics had concentrated in the quarters in the northeast of the new city. Given the preference of the Muslims for large gardens that supported small-scale agriculture, and the lower original economic status of Catholic families, the northeast quarters developed with a denser urban fabric based on smaller plots compared to Muslim quarters in the west, albeit using the same traditional house type. The subsequent densification of the street network toward the northeast led to the shifting of the integration core away from the ancient arterial Dukagjin Rd (Via Publica) to the new boulevard Great Rd. further east., and the creation of a new center in the upper city. The study of Shkodër's history of urban form is important for informing historical preservation and urban design and contributes towards comparative and historical urban studies in the region and beyond.

\section{Acknowledgments}

The author thanks Florian Nepravishta and Etleva Bushati who helped obtain historical maps and photographs.

\section{References}

Azimzadeh, M., \& Klarquist, B. (2001). Metamorphosis and evolution of cities: the status of planning and urban design. Proceedings of the $3^{\text {rd }}$ International Space Syntax Symposium. (51.1-51.15) Atlanta: Georgia Institute of Technology.

Barbie du Bocage, J-D. (1820). Plan de la ville de lanina. Map, From Bibliothèque Nationale de France.

Bafna, S. (2003). Space syntax: A brief introduction to its logic and analytical techniques. Environment and Behavior, 35(1), 17-29.

Bošković, Đ., Mijović P., \& Kovačević M. (1981). Ulcinj I, 16, Beograd: Arheološki Institut.

Braudel, F. (1972). The Mediterranean and the Mediterranean World in the age of Philip II. New York: Harper \& Row.

Busch-Zantner, R. (1932) Zur Kenntnis der osmanischen Stadt. Geographische Zeitschrift, 38(1), 1-13.

Bushati, H. (1998). Shkodra dhe motet: Traditë, ngjarje, njerëz. Shkodër: Idromeno.

Blumi, I. (2010). Adding new scales of history to the Eastern Mediterranean: Illicit trade and the Albanian. In B. Kolluoglu and M. Toksoz (Eds.) Cities of the Mediterranean: from the Ottomans to the present day (116-138). London: I. B. Tauris.

Braudel, F. (1972). The Mediterranean and the Mediterranean World in the age of Philip II. New York: Harper \& Row.

Çelik, Z. (1986) The remaking of Istanbul: Portrait of an Ottoman city in the nineteenth century. Seattle: University of Washington Press.

Dankoff, R. \& Elsie R. (2000). Evliya Çelebi in Albania and adjacent regions: Kosovo, Montenegro, Ohrid: the relevant sections of the Seyahatname. Leiden and Boston: Brill.

D'Ascensi \& Miserocchi (1938). Scutari, F1 and F2. Map, scale 1:500. Firenze: Istituto Geografico Militare.

Dumont, A. (1874). Le Balkan et l'Adriatique. Paris: Didier et Cie.

Elsie, R. Early photography in Albania, http://www.albanianphotography.net

Fouillade-Orsini, H. (2018). Belgrade's urban transformation during the $19^{\text {th }}$ century: A space syntax approach. Geographica Pannonica, 22(3), 219-229.

Hillier, B. \& Hanson J. (1984). The social logic of space. Cambridge: Cambridge University Press.

Hobbs, H.F.C. (1913). Map of Scutari Albania. Map, scale 1:6,336. From The National Archives, Kew, UK. 
Hohenberg, P. M, \& Lees L. H. (1995). The making of urban Europe, 1000-1994. Cambridge: Harvard University Press.

Hoxha, G. (2003). Scodra dhe Praevalis në antikitetin e vonë. Shkodër: Camaj Pipa.

Griffiths, S. (2010). Temporality in Hillier and Hanson's theory of spatial description: Some implications of historical research for space syntax. The Journal of Space Syntax, 2(1), 73-96.

Gruber, S. (2006). The quarters of Shkodra in 1918: Differences and similarities. Ethnologia Balkanica,10, 141-158.

Ippen, T. A. (1907). Skutari und die nordalbanische Küstenebene. Sarajevo: Kajon.

Jireček, K. (1916). Skutari und sein Gebiet im Mittelaltern. In L. von Thallóczy (Ed.) Illyrisch-Albanische Forschungen 1, (94-124). München and Leipzig: Duncker \& Humblot

Kamsi, V. (1976). "Shtrirja e qytetit të Shkodrës në kohën e lashtë dhe të mesme." Monumentet, 11, 117125.

Karamustafa, A. T. (1992). Introduction to Ottoman cartography. In J. B. Harley \& D. Woodward (Eds.) The History of cartography: Volume two, book one: Cartography in the traditional Islamic and South Asian societies. (3-11). Chicago and London: The University of Chicago Press.

Karimi, K. (2000). Urban transformation and spatial transformation: Preserving the fragments or maintaining the 'spatial spirit'. Urban Design International, 5, 221-231.

Kiel, M. (1990). Ottoman architecture in Albania 1385-1912. Istanbul: Research Center for Islamic History, Art and Culture.

Korkuti, M. \& Petruso K. M. (1993). Archaeology in Albania. American Journal of Archaeology, 97(4), 703743.

Krstikj, A. (2013). Values of the historic urban form of Skopje's old bazaar based on analysis of the Ottoman urban strategy. Ph.D. Dissertation, Osaka University.

Kubat, A. S. (1997). The morphological characteristics of Anatolian fortified towns. Environment and Planning B: Planning and Design, 24(1), 95-123.

Kubat, A. S. (1999) The morphological history of Istanbul. Urban Morphology, 3, 28-41.

Marshall, S. (2005). Streets and Patterns. London: Spon.

Marubi Photo Collection, http://www.marubi.gov.al.

Medeiros, V., de Holanda, F., Trigueiro, E. (2003). From compact colonial villages to sparse metropolis. Proceedings of the $4^{\text {th }}$ International Space Syntax Symposium, (12.1-12.16). London: University College London.

Mijović, P. \& Kovačević M. (1975). Gradovi i utvrđenja u Crnoj Gori. Beograd: Arheološki Institut. Posebna Izdanja 13.

Miklosich, F. R. von. (1858). Monumenta serbica spectantia historiam serbiae bosnae ragusii. Vienna: Apud Guilelmum Braumüller.

Nadin, L. (2010). Statutet e Shkodrës në gjysmën e parë të shekullit XIV me shtesat deri më 1469: Statuti di Scutari della prima metá del secolo XIV con de addizioni fino al 1469. Tirana: Onufri.

Pedani, M. P. (2008). Ottoman merchants in the Adriatic: Trade and smuggling. Acta Histriae, 16(1-2), 155172.

Peponis, J. \& Wineman, J. (2002). Spatial structure of environment and behavior. In R. B. Bechtel \& A. Churchman (Eds.) Handbook of Environmental Psychology, (271-291). New York: John Wiley.

Petruccioli, A. (2007). After amnesia: Learning from the Islamic Mediterranean urban fabric. Bari: ICAR.

Pinon, P. (2008). Ottoman cities of the Balkans. In S. Khadra Jayyusi, R. Holod, A. Petruccioli, \& A. Raymond (Eds.), The city in the Islamic world, Handbook of Oriental studies, Book 94, (143-158). Leiden and Boston: Brill.

Rashid, M. (2021) Physical space and spatiality in Muslim societies: Notes on the social productions of cities. Ann Arbor: University of Michigan Press.

Raymond, A. (2008). The Spatial organization of the city. In S. Khadra Jayyusi, R. Holod, A. Petruccioli, \& A. Raymond (Eds.), The city in the Islamic world, Handbook of Oriental studies, Book 94, (47-70). Leiden and Boston: Brill.

Read, S. (2000). The grain of space in time: The spatial/functional inheritance of Amsterdam's centre. Urban Design International, 5, 209-220.

Riza, E. (1972). Banesa popullore në Shkodër gjatë shekujve XVII - XIX. Monumentet, 4, 141-184.

Rossi, C. \& Boroli M. (1923). Harta topografike e Shkodres botue prej etenve jezuit. Map. Novara: Istituto Geografico De Agostini.

Royal Italian Navy (1918). Bocche di Cattaro, Scutari, Aerial Photograph, MCRR Album C 120, From Museo Centrale del Risorgimento, Roma. 
Schmitt, O. J. (2001). Das Venezianische Albanien: (1392-1479). Munich: Oldenbourg.

Shkodra, Z. (1984). Qyteti shqiptar gjatë rilindjes kombëtare. Tiranë: Akademia e Shkencave e Republikës Popullore Socialiste të Shqipërisë.

Shpuza, E. (1995). Spatial typology of traditional Albanian town houses. MSc. Thesis, University College London.

Shpuza, E. (2009), Evolution of street networks in Adriatic and lonian coastal cities 1769-2007. In Koch, D.,

Page | 128 Marcus, L. and Steen J. (Eds.) Proceedings of the $7^{\text {th }}$ International Space Syntax Symposium, (101:1-15). Stockholm: KTH Royal Institute of Technology.

Shpuza, E. (2014). Allometry in the syntax of street networks: Evolution of Adriatic and Ionian coastal cities 1800-2010. Environment and Planning B: Planning and Design, 41(3), 450-471.

Shundovska, M. (2015). Urban transformation of Bitola through the notes of planning documentation: The Interpretation of military architecture into the urban patterns - memory, reality, and opportunity. PhD Dissertation, Politecnico di Milano.

Šufflay, M. von (1924). Städte und Burgen Albaniens: Hauptsächlich Während des Mittelalters. Wien: Hölder-Pichler-Tempsky.

Topçu, M. (2019). Morphological structures of historical Turkish cities. ICONARP International Journal of Architecture and Planning, 7, 212-239.

Tuzi, E., Bushati, E. \& Nepravishta, F. (2014). Ottoman military and administrative complex in the inner city of Shkodra. Proceedings of Second International Conference on Research and Education. Shkodër: Luigj Gurakuqi University.

Valentini, J. (1967-1979) ed. Acta Albaniae Veneta saeculorum XIV et XV. 25 vols. Palermo: Typis Josephi Tosini.

Yenen, Z. (1992). Social and religious influences in the form of early Turkish cities of the Ottoman period. Journal of Architectural and Planning Research, 9(4), 301-314.

Zamputi, I. (1963). Relacione mbi gjendjen e Shqipërisë veriore dhe të mesme në shekullin XVII, v1 16101634. Tiranë: Universiteti Shtetëror i Tiranës.

Zamputi, I. (1977). Regjistri i kadastrës dhe i koncesioneve për rrethin e Shkodrës 1416-1417. Tiranë: Akademia e Shkencave e Republikës Popullore Socialiste të Shqipërisë. Italian to Albanian translation of Cordignano, F. (1942). Catasto Veneto di Scutari e registrum concessionum 1416-1417. Roma: Cuore di Maria.

Zaninović T., Palaiologou G., Griffiths, S., and Bojanić Obad Šćitaroci, B. (2018). Urban landscape and spatial heritage: The case of gateway-pathways in Zagreb, Croatia. The Historic Environment: Policy \& Practice, 9(3-4), 274-305.

\section{Resume}

Ermal Shpuza is a Professor of Architecture at Kennesaw State University, USA. His research interests span spatial analysis, urban morphology, complex systems in cities, workplace design, and design computing. He studies the evolution of Adriatic and lonian coastal cities, urban transformation in the Balkans, shape description, the affinity between block shape and street patterns, and interaction between floorplate shape and circulation in buildings. He teaches courses in spatial analysis, urban design and planning theory, and environmental technology, and studios in urban design and environmental design. He received his architectural education from the Polytechnic University of Tirana, the Bartlett, University College London, and the Georgia Institute of Technology. 